\title{
Wind Energy in Poland - economic analysis of wind farm
}

\author{
Renata Gnatowska ${ }^{1, *}$, Agnieszka Wąs ${ }^{1}$ \\ ${ }^{1}$ Czestochowa University of Technology, Institute of Thermal Machinery, Poland
}

\begin{abstract}
Wind power generation is the most dynamically developing branch of renewable energy sector in Poland. The high price of coal and its negative environmental impact result in ever growing support for the renewable energy in the energy sector. Wind power industry produces clean energy, but costs of investments are very high. Process of creating a wind farm is very long and complicated. It requires the knowledge of many disciplines such as law, economics, energetic. The aim of this paper was study the state and the development of the wind power sector, especially wind farm in Poland. The economic analysis on investment in wind farm in Poland according to a new act on renewable energy sources was presented. The subject of this analysis was to estimate profitability of wind farm project $40 \mathrm{MW}$ capacity. The analysis includes the comparison of various support systems - the system of green certificates and the new - auction model on the profitability of investment in wind farm. This aims to show how important is appropriate government support for producers of green energy words.
\end{abstract}

\section{Wind Energy in Poland - present state and prospects of development}

Poland, as of the European Union member is obliged to execute the decisions that were taken by the Council of the EU. Given RES talking about the Europe 2020 strategy, which talks about the growth of the share of RES in total energy production to $20 \%$ compared to 1995. The constant development of renewable energy sources also indicate the provisions of the Paris Climate Change Conference 2015 (COP21) - (ang. United Nations Framework Convention on Climate Change, the 21st Conference of the Parties, COP21), the extent of which is global, not just European. For the development of renewable energy sources it is mainly the speed limit climate change caused by emissions of carbon dioxide, is produced by the combustion of fuels [1-3].

Wind power generation is the most dynamically developing branch of renewable energy sector in Poland (see figure 1). According to the data of the Energy Regulatory Office (URE), the total power of wind turbines in Poland was 2497 MW, at the end of March 2012. In the end of March 2016 there were 1129 wind installations (single turbines and farms) operating in Poland, of the total power of $5660 \mathrm{MW}$, which results in a nearly

\footnotetext{
* Corresponding author: gnatowska@imc.pcz.czest.pl
} 
double increase in power [4]. There are a few dozens of operating wind farms, mainly located in the northern part, the central part of the country (Fig. 2).

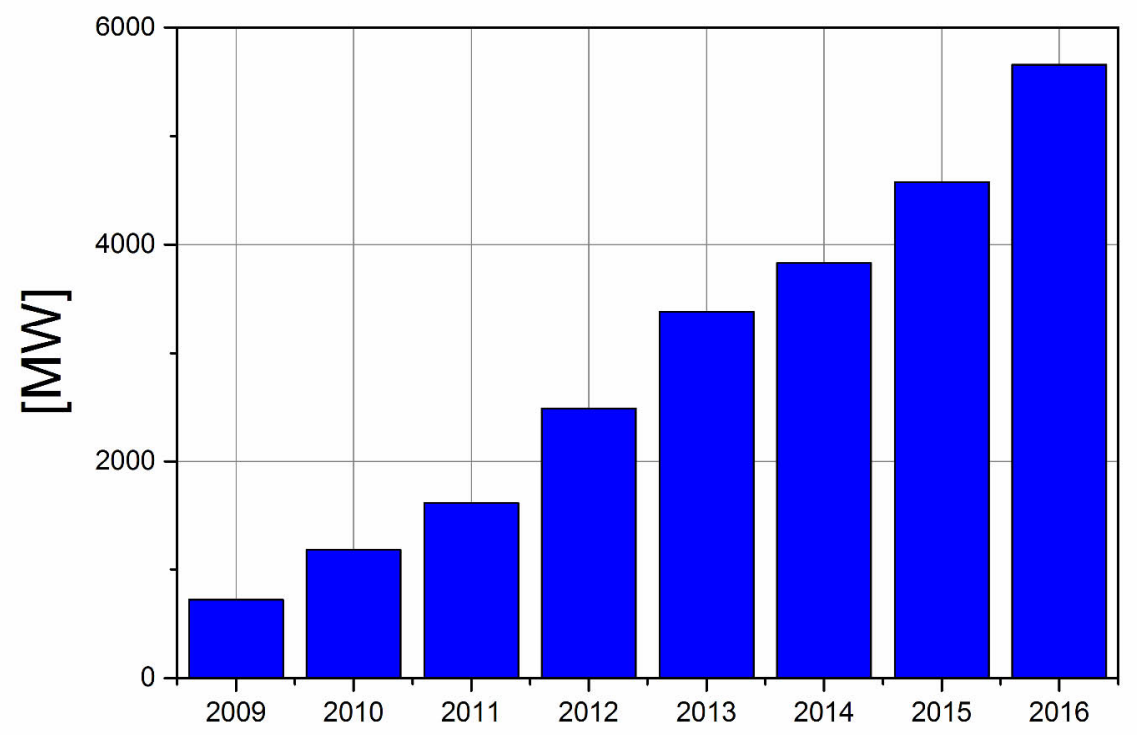

Fig. 1. Capacity installed in Wind farm in Poland [MW] [4].

Reforms introduced by the Renewable Energy Sources Act 2015 [5], marked a significant step forward, however, subsequent amendments to the RES Act have illustrated how the Polish government is in a difficult position of striking a balance between developing RES for energy diversification and rescuing coal industry. 


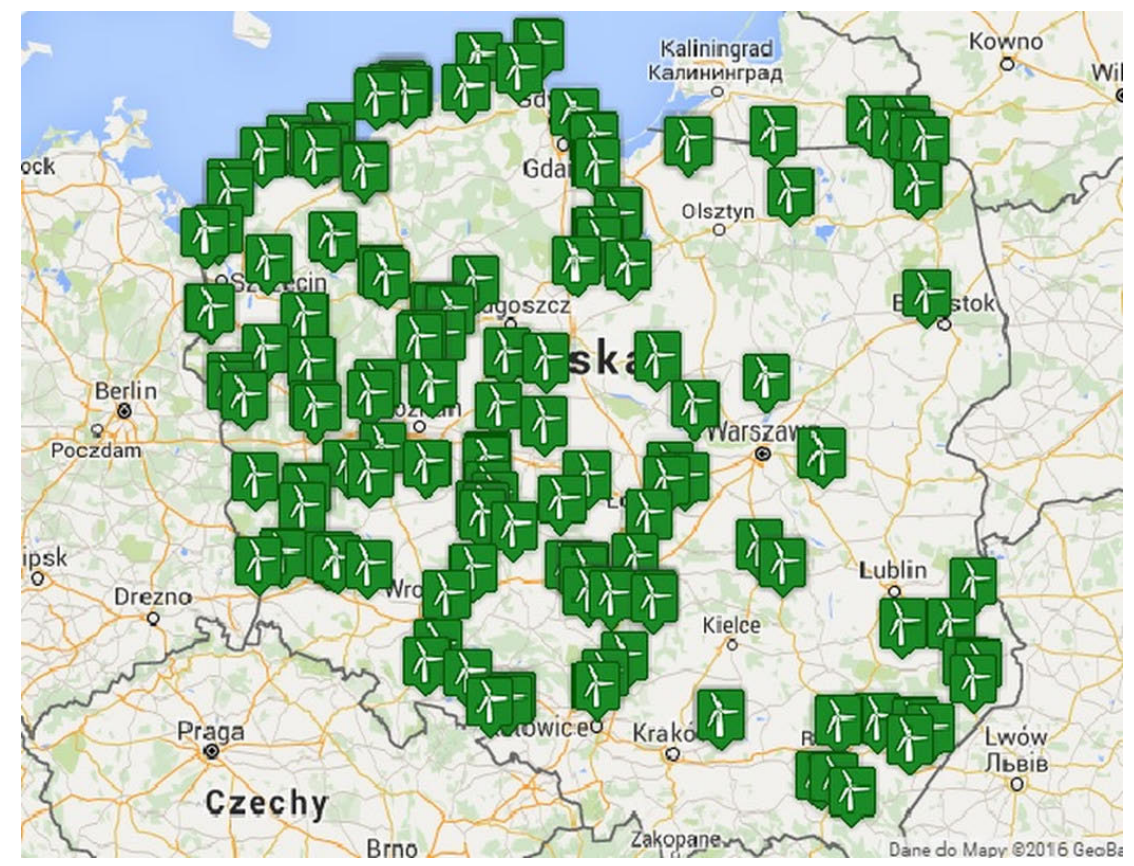

Fig. 2. Map of wind energy installations in Poland [6].

The RES Act, (which is the implementation of the provisions of Directive 2009/28/EC into Polish law), sets a new regulatory and economic framework for investments in renewable projects in Poland [7]. The Auction System replaces the previous renewable energy investment incentive system, under which installations were required to obtain tradable/transferable certificates of origin from RES ('Green Certificates') and to sell property rights arising from those one. The property rights arise once the Green Certificates are registered on a register of certificates operated by the Polish Power Exchange 'Towarowa Gielda Energii S.A.' ('TGE'). The Green Certificates can be traded on a regulated market. The value of Green Certificates is set by the market. The Green Certificate System had worked well during 2000-2010, due to the development of 'cofiring'. The rapid increase in biomass co-firing created an enormous oversupply of Green Certificates. In March 2016, the oversupply was over 20 TWh [8]. The oversupply of Green Certificates caused their value to drop significantly (from around PLN 280/MWh in early 2012 to less than PLN 100/MWh by February 2013 [9]). The outcome was a reduction of profitability of RES projects. Poland has also severely limited growth in wind generation by passing the Act, aimed at restricting wind power development. The purpose of Act on Windfarms [10] is to determine places where wind power plants can be built and sets out the minimum distance required between a wind power plant and residential buildings, forests or national parks. The distance is set at 10 times the height of a wind power plant (in practice approximately between 1.5 and $2 \mathrm{~km}$ ). This requirement seems very strict. It will be a challenge to find plots of land which meet the statutory distance requirement, in many cases it will be impossible to build new or expand already existing plants. In addition, the Act quadruples the rate of tax payable on existing turbines, making them unprofitable [10].

The aim of this paper was study the state and the development of the wind power sector, especially wind farm in Poland. The economic analysis on investment in wind farm in Poland according to a new act on renewable energy sources was presented. The subject of this analysis was to estimate profitability of wind farm project $40 \mathrm{MW}$ capacity. The 
analysis includes the comparison of various support systems - the system of green certificates and the new - auction model on the profitability of investment in wind farm. This aims to show how important is appropriate government support for producers of green energy. The new formal and legal framework for the wind power sector in Poland was described in relation to the new Renewable Energy Sources Acts [5, 10-11]. The economic analysis of three scenarios of the development of the wind power sector in Poland was presented.

\section{Wind farm case study}

In order to estimate the economic efficiency of wind farm examines the case of a wind farm with a capacity of $40 \mathrm{MW}$, located on Polish territory. Where the average annual wind velocity is $6 \mathrm{~m} / \mathrm{s}$. The analyzed wind farm consists of 20 wind turbines of the Danish company VESTAS - model V80 2.0 MW. On the basis of this chart below (Figure 3), estimated annual energy production by the wind farm.

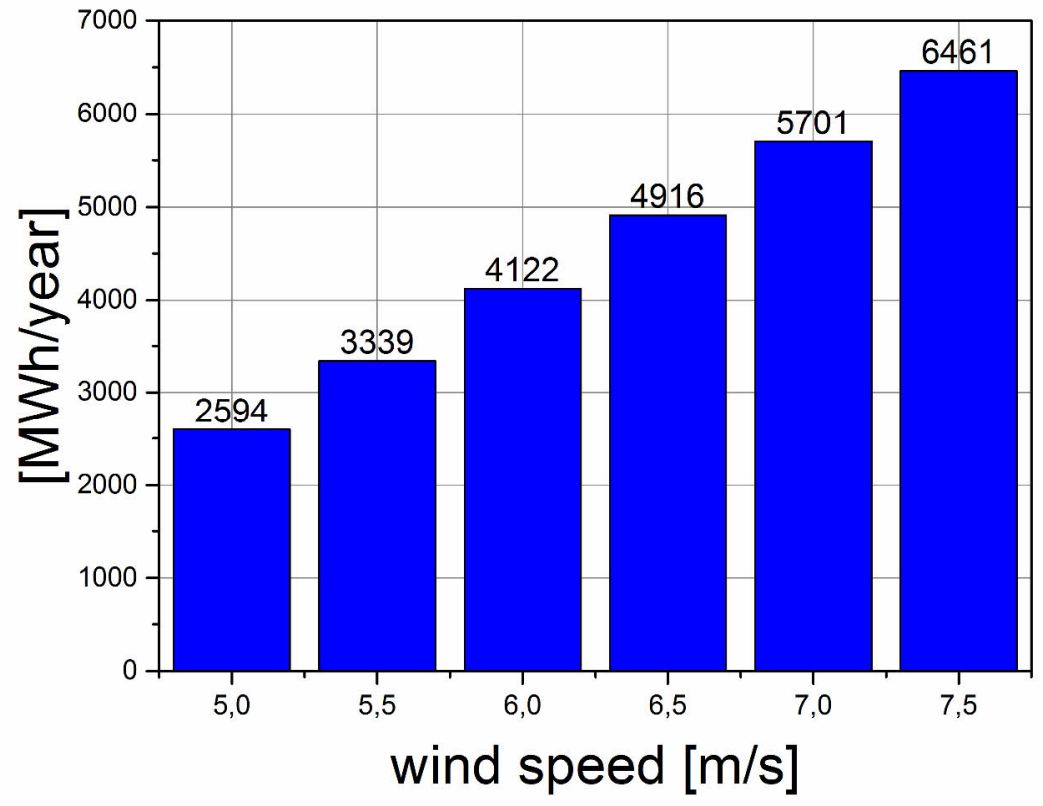

Fig. 3. The average annual production of electricity by turbine VESTAS V80 2.0MW [12].

The investment costs of a wind farm was estimated at 252.5 million PLN, of which the largest part was the purchase of wind turbines, representing $81 \%$ of investment costs (see Tab. 1). In order to analyze the efficiency of investment in a wind farm was estimated operating costs (Tab. 2). [3, 13, 14] and sources of financing. 
Table 1. Summary of investment costs of analysed wind farm.

\begin{tabular}{|c|c|c|}
\hline COMPONENTS & COST [PLN] & {$[\%]$} \\
\hline Wind turbines & 205787500 & 81,5 \\
\hline $\begin{array}{c}\text { Project (with costs of } \\
\text { research) }\end{array}$ & 11362500 & 4,5 \\
\hline $\begin{array}{c}\text { Construction work } \\
\text { (with work infrastructure) }\end{array}$ & 17675000 & 7 \\
\hline $\begin{array}{c}\text { Connecting to network } \\
\text { Internal energy network }\end{array}$ & 3787500 & 1,5 \\
\hline Total costs & 252500000 & 100,00 \\
\hline
\end{tabular}

Table 2. Summary of the annual operating costs of a wind farm.

\begin{tabular}{|c|c|c|}
\hline COMPONENTS & COST [PLN] & {$[\%]$} \\
\hline Property tax & 2000000 & 27,36 \\
\hline Service and maintenance & 3300000 & 45,14 \\
\hline Balancing the energy & 1500000 & 20,52 \\
\hline Insurance & 360000 & 4,92 \\
\hline Land rent & 150000 & 2,05 \\
\hline Total costs & 7310000 & 100,00 \\
\hline
\end{tabular}


Case Study is funded by the following sources: own contribution, financing and credit for 10 years, the interest rate is $2 \%$ per annum. The annual installment of the credit is a fixed amount. The structure of the funding sources are presented in table 3.

Table 3. Summary of the annual operating costs of a wind farm.

\begin{tabular}{|c|c|c|}
\hline COMPONENTS & VALUE [PLN] & PERCENTAGE [\%] \\
\hline OWN CONTRIBUTION & 152500000 & 60,40 \\
\hline FINANCING & 40000000 & 15,84 \\
\hline CREDIT & 60000000 & 23,76 \\
\hline
\end{tabular}

\section{Analysis of economic efficiency of wind farm}

Return on investment in a wind farm in the Polish conditions is the subject of very extensive. The profitability of such an investment is influenced not only the amount of energy produced, which results directly from the wind speed occurring in the area. Attention should be paid to several other factors. Among other things, the volatility of prices of electricity sales (sales of "green energy" is subject to special rules). Construction of a wind farm requires huge financial investment, so you should carefully examine all factors that could affect its economic efficiency and identify risks.

\subsection{Definition of parameters}

In order to assess the economic efficiency will be used three indicators, which will determine not only whether the investment is profitable, but also determine in which year of the wind farm will start to make a profit. The cash flow $(C F)$, which specifies the aggregate for a given period cash flows. It is the difference of income and expenditure [13]. This ratio is determined using the expression:

$$
C F=\sum_{t=0}^{n}(\text { earinings }- \text { costs })_{t}
$$

were: $t$ - years of investment.

The net present value $(N P V)$ of the flow of profits over simulation time is calculated as the aggregated value of discounted annual profits and is given by:

$$
N P V=\sum_{t=0}^{n}\left[C F_{t} /(1+r)_{t}\right]-I_{0}
$$

where: $C F$ - net cash inflow during the period $t, r$ - discount rate, $\mathrm{I}_{0}$-total initial investment costs, $t$ - number of time periods, $n$ - the terminal year of the simulation.

The internal rate of return $(I R R)$ is the discount rate for which the $N P V$ is equal to 0 . The investment is profitable when the $I R R$ assumes a greater value of the discount rate, and the difference between them is of greater value, the investment is more profitable $(I R R>r)$. This indicator can be represented by the formula [13-14]:

$$
\sum^{n}{ }_{t=0}\left[C F_{t} /(1+r)_{t}\right]-I_{0}=0
$$




\subsection{Analysis}

Economic analysis includes three cases of investment in a wind farm. For each, the discount rate is $5 \%$ and the duration of the investment 25 years. Case studies vary in way of the sale of energy:

- CASE A - the sale of energy takes place at auction, and the earnings of the wind farm is estimated at PLN 385/MWh [15],

- CASE B - the sale of energy takes place in a system of "green certificates", where the total purchase price consists of the amount from the sale of certificates, which the average value in 2015 amounted to PLN 123.6/MWh , and the price of the average quarterly price of electricity determined in July 2016 year by the URE to 173.5 PLN/MWh [16],

- CASE C - the sale of energy takes place without the support system.

The comparison was made for different cases of energy sale from the wind farm(various support schemes). This analysis seems to be interesting from the point of view of investors on Poland energy market. In frame of this work was analyzed the new auction system, the existing system of green certificates and the lack of support energy sales for the producers of energy from renewable sources. The risk of erroneous estimation of investment profitability is high, because the auction system is a new system that has not yet started its operation and provide a stable selling price of energy for the producers of "green energy".

The premise of the auction system are stable prices in the perspective of 15 years, while the above analysis applies to the operation of a wind farm in 25 years. For the purposes of analysis it was assumed that the selling price of electricity for the described event will be fixed in 25-year time horizon and will amount to 385PLN per MWh.

Analysis of the profitability of the investment functioning in the system of green certificates is a bit more complicated, what is the cause of instability in their prices. Average price of the certificate was in 2009 - 250.03 PLN/MWh, while in later years has experienced drastic declines - for example in February 2013 and June 2015 amounted to approx. $100 \mathrm{PLN} / \mathrm{MWh}$, and now it is no longer even $40 \mathrm{PLN} / \mathrm{MWh}$ [16]. Also note that if the sale is not their only source of income of a wind farm. The wind farm sells certificates are merely certificates of origin, and the electricity is sold at standard prices prevailing on the market. In this case it will be PLN 173.5/MWh. This price will also be taken into account for the calculation for the wind farm, which does not exist in any of these support systems. 


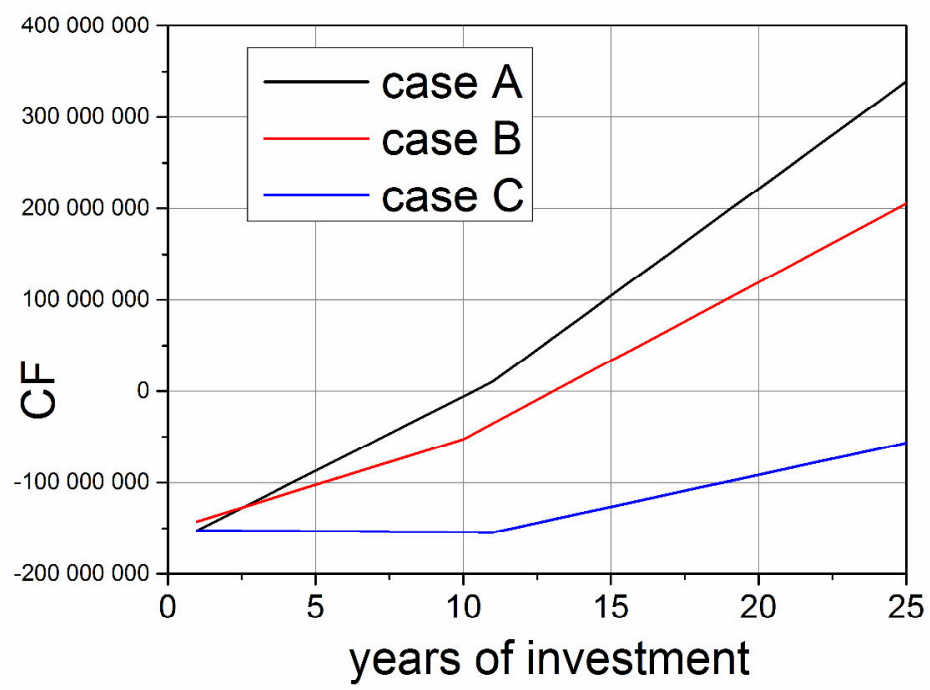

Fig. 4. Values of CF for the cases A, B and C.

The graph on Fig. 4 summarizes the value of the paramerer $C F$ for all three cases. It shows that the best profitability shows for case A operating in the auction system, slightly worse results are achieved system of green certificates. Economic viability for 25 years operation of the farm does not show the wind farm, which does not receive any support. $C F$ ratio does not take into account the changing value of money over time, so in order to determine a more accurate economic viability should take into account the value of the index $N P V$, the results of which are summarized on Fig. 5.

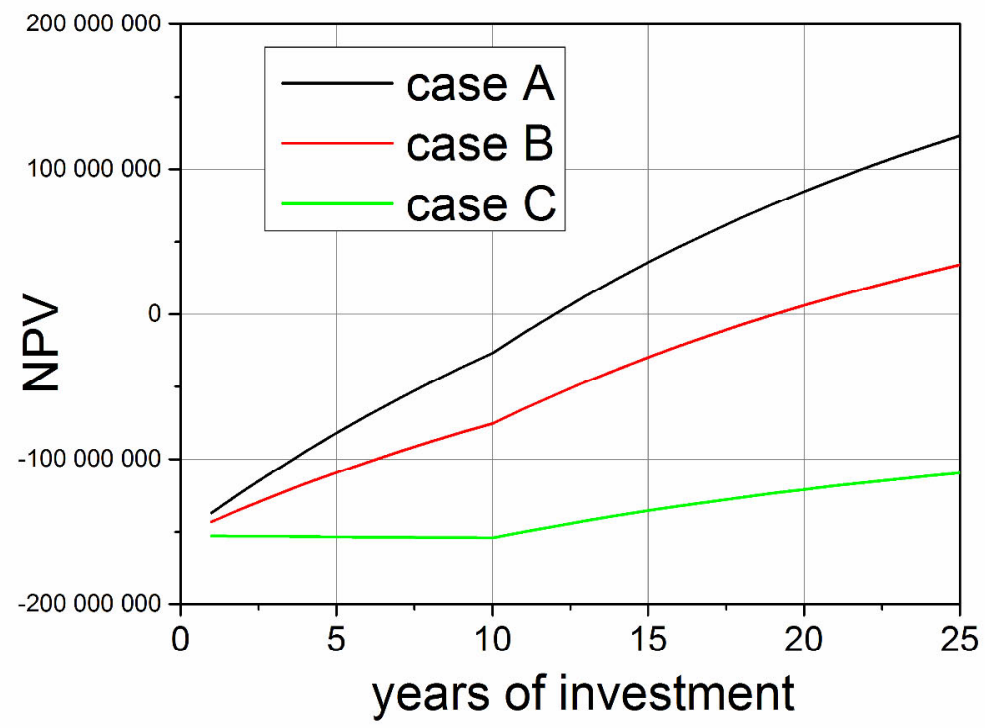

Fig. 5. Values of NPV for the cases A, B and C. 
According to the above graph (Fig. 5) can be identified in which year each of the cases will begin to be profitable. Both indicators $C F$ and $N P V$ best results achieved for case A. According to the parameter $N P V$ wind farm operating in the auction system will start to be profitable in the 12th year of the investment. In the case of green certificates will be the 20th year of operation of the investment. In the case of a system that does not receive support investment in the wind farm will not be profitable.

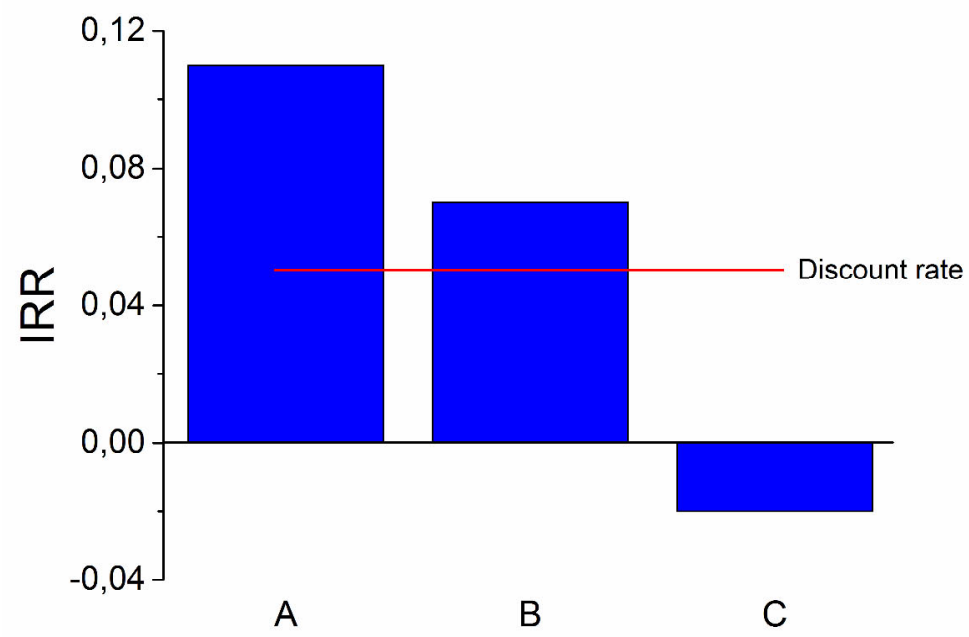

Fig. 6. Values of IRR for the cases A, B and C in the 25. year of investment.

The graph above (Fig. 6) showing the results of $I R R$ in the 25th year of the investment confirms the results obtained for indicators of $C F$ and $N P V$. In cases $\mathrm{A}$ and $\mathrm{B}$ the value of IRR is higher than the accepted level of $5 \%$ discount rate. For the case $\mathrm{C} I R R$ in the 25 th year has a value $-2 \%$, which indicates a failure of the investment.

The obtained results allow to become conscious of what the most important are costs and minimize them, which is one of the most important contributions. It will be useful to improve the competitiveness of floating wind farms in the future. The authors are aware that the presented results do not contain a comprehensive analysis. The further study is needed to determine additional questions regarding the profitability changes according to wind resource, wind farm's lifetime or carbon emissions. Obtain results can be enhanced also by feedback from relevant people related to the operation and maintenance activities taking place at the wind farm.

\section{Summary}

Made in the work of analysis clearly showed that the operation of a wind farm in conditions where it has no support is undoubtedly highly unprofitable. In addition, there is no certainty that for every reported investment auctions will be allocated. This situation indicates that the development of RES installations, including of course the wind energy influenced by the state authorities. Support in the form of the auction will receive probably investors who will be needed to fulfill the minimum targets of the strategy for 2020. In the case of our country should consider, therefore, that certainly tends to the production of "green energy" because of the benefits that entails the production of or only from a sense of obligation to fulfill international agreements. Favor of the government to promote the 
development of renewable energy over the required level, resulting with international obligations is therefore a question mark, which increases the risk of the economic efficiency of this type of investment and discourages potential investors. It appears that the government tends to reduce support for the RES energy and will most likely treat biomass installations especially as opposed to wind farms.

The new Act on Windfarms might suggest an occasion to invest in offshore wind farms on Baltic Sea. The productivity of the sea farms are twice better than the onshore and the location is not so controversial [17]. The first Polish offshore wind farm is projected to be operational in 2021.

\section{References}

1. M.M. Al-Maghalseh, E.M. Maharmeh, Procedia Computer Science 83, 790-798 (2016)

2. P.J. Simons, W.M. Cheung, Journal of Cleaner Production. (2016).

3. M. Ligus, Efektywność inwestycji $w$ odnawialne źródła energii. Analiza kosztów $i$ korzyści (CeDeWu, Warszawa, 2012)

4. The Energy Regulatory Office website, http://www.ure.gov.pl/pl/rynki-energii/energiaelektryczna/odnawialne-zrodla-ener/potencjal-krajowy-oze/5753,Moc-zainstalowanaMW.html [01.09.2016 r.]

5. The Act on renewable energy sources, Ustawa $\mathrm{z}$ dnia 20 lutego $2015 \mathrm{r}$. o odnawialnych źródłach energii (Dz.U. 2015 poz. 478)

6. The Energy Regulatory Office website, http://www.ure.gov.pl/uremapoze/mapa.html [01.09.2016 r.]

7. Report: Renevable Investments in Poland 2016 - Onshore Wind \& Photovoltaic, http://wysokienapiecie.pl/energy-poland/1229-report-renevable-investments-in-poland2016-onshore-wind-photovoltaic [01.09.2016 r.]

8. Association of Energy Trading Report, "status on 31 March, 2016", http://webcache.googleusercontent.com/search?q=cache:tIqKJfjKZ8EJ:www.toe.pl/pl/ wybrane-dokumenty/rok-2016\%3Fdownload\%3D1462:electricity-and-gas-market-inpoland-status-on-31-march-2016-toe-report+\&cd=1\&hl=en\&ct=clnk\&gl=uk, [01.09.2016 r.]

9. Argus Media. Polish renewable subsidy crash hits biomass, http://www.argusmedia.com/pages/NewsBody.aspx?id=836517\&menu=yes [01.09.2016 r.]

10. The Act on Windfarms, Ustawa $\mathrm{z}$ dnia 20 maja 2016 r. o inwestycjach w zakresie elektrowni wiatrowych (Dz.U. 2016 poz. 961)

11. Ustawa z dnia 22 czerwca 2016 r. o zmianie ustawy o odnawialnych źródłach energii oraz niektórych innych ustaw (Dz.U. 2016 poz. 925)

12. Polish Wind Energy Consulting webside, http://www.polishwindenergy.com/index.php/elektrownie-wiatrowe-w-polsce/item/39vestas-v80-2-mw.html [01.09.2016 r.]

13. Z. Lubośny, Farmy wiatrowe $w$ systemie elektroenergetycznym (Wydawnictwo Naukowo-Techniczne, Warszawa, 2009)

14. R. Gnatowska, A. Wąs, Inż. Ochr. Środow. 18, 1 (2015)

15. The Energy Regulatory Office website, http://www.ure.gov.pl/pl/rynki-energii/energiaelektryczna/aukcje-oze/dokumenty/6539,Ceny-referencyjne.html [01.09.2016 r.]

16. The Energy Regulatory Office website, http://www.ure.gov.pl/pl/tagi/21, srednieceny.html [01.09.2016 r.]

17. S.O. Effiom, B.N. Nwankwojike, F.I. Abam, Energy Reports 2, 48-53 (2016) 